\title{
ROOFTOP RAINWATER HARVESTING: ALLEVIATING WATER SHORTAGES AT THE HOUSEHOLD LEVEL
}

\author{
IBRAHIM ALAMEDDINE ${ }^{1}$, AMANI MAJZOUB ${ }^{1}$, MAJDI ABOU NAJM ${ }^{1,2} \&$ MUTASEM EL-FADEL $^{1}$ \\ ${ }^{1}$ Department of Civil and Environmental Engineering, American University of Beirut, Lebanon \\ ${ }^{2}$ Department of Land, Air and Water Resources, UC Davis, USA
}

\begin{abstract}
Population growth and development coupled with potential climate change impacts are invariably associated with chronic water shortages particularly in arid and semi-arid regions. In this study, we examined the socioeconomic feasibility of implementing rainwater harvesting systems (RWHS) on building rooftops to alleviate chronic water shortages. Examining the socio-economic factors affecting the willingness of people to participate in such programs, it was found that education and the availability of outdoor space affected the rate of participation positively, while the age of the respondent and the number of floors in a building decreased people's keenness to participate. The cost of harvested rainwater per cubic meter was found to range between $\$ 0.16$ and $\$ 0.28 / \mathrm{m}^{3}$, which compares favourably with the existing public network tariffs $\left(\$ 0.37 / \mathrm{m}^{3}-\$ 1.4 / \mathrm{m}^{3}\right)$ and provides major savings when compared to the costs associated with different adaptation measures commonly used by residents (reverse osmosis system $=\$ 1.36 / \mathrm{m}^{3}$; water tankers $=\$ 5.64^{-10} / \mathrm{m}^{3}$ ). On average, a household with a monthly income below $\$ 1,500$ was willing to invest $\$ 0.54 / \mathrm{m}^{3}$ in a RWHS compared to $\$ 2.34 / \mathrm{m}^{3}$ for those whose monthly income was above $\$ 6,000$; for both income groups their average reported investment costs represented around $1 \%$ of their monthly income. At the economic viability level, a RWHS proved advantageous for a single household with 5 occupants, while harvested quantities for a multi-storey residential building with 50 occupants or more were relatively small in comparison to actual demands. Concerns over the water quality of the harvested rainwater were documented in the study area, with bacterial contamination proving to be a major concern.
\end{abstract}

Keywords: rainwater harvesting, willingness to participate, willingness to pay, water quality.

\section{INTRODUCTION}

Worldwide increases in water demand coupled with a decrease in conventional water supplies have promoted the development and use of unconventional water sources. While desalination remains the most common alternative sought in water-stressed urban areas, its financial and environmental burdens remain a barrier in many regions [1]. Rainwater harvesting can provide a renewable source of clean water suitable for domestic and landscape uses; yet its use is often limited to small-scale applications [2], [3]. It has been successfully applied in many countries such as Germany [3], [4], Australia [5], Spain [6]-[8], Nepal [9], India [10], and the US [11] amongst others. Technically, the components of a rooftop rainwater catchment system typically include a collection area (roof), a conveyance system, a cistern or storage tank, a delivery system (gravity or pump), and a treatment system whose processes depend on the quality and intended use of the collected water.

Several studies have aimed to better understand the viability of rainwater harvesting, taking into account its quality [7], [12], [13], financial feasibility [6], [8], social acceptance [9], [14], and environmental impacts [15]. The success of rainwater harvesting programs is strongly associated with regulations and incentives aimed at promoting its adoption. For example, in the US, rainwater harvesting is mandatory for new buildings in Arizona and New Mexico, and tax exemptions are given for buildings in Texas [16]. In Europe, Belgium promulgated regulations that require all new buildings with roof areas greater than $100 \mathrm{~m}^{2}$ to install a rainwater harvesting system (RWHS); Germany on the other hand offers rain tax reductions for properties that collect rainwater instead of diverting the flow to the local storm 
sewers [3]. Similarly, several municipalities in Spain approved water saving regulations that mandate new buildings with garden spaces to install rainwater collection tanks [8].

Water scarcity and the imbalance between conventional water sources and demands in urban Mediterranean areas have promoted the adoption of rainwater harvesting. As such, interest in implementing urban rainwater harvesting has been increasing across the Mediterranean basin, especially in Spain [6], [8], [9], Malta [17], Italy [18], Greece [13], and the Palestinian Territories [19]; all of which are facing water shortages that are projected to exacerbate in the coming decades due to population growth and development as well as the effect of climate change [20]. Generally, these countries share similar Mediterranean climatic conditions characterized by long, hot, dry summers and short, cool, rainy winters. The potential of rainwater harvesting in supplementing domestic water demands at the residential level varies significantly depending on location, ranging from $<1 \%$ to nearly $80 \%$ of the total demand. This wide range is attributed to variations in climatic conditions, water demands, and levels of urbanization [21]. Domènech and Saurí [22] reported that $16 \%$ of the total domestic water demand in Sant Cugat del Valles, Spain, was met through rainwater harvesting. In Jordan, the range of water saving as a result of rainwater harvesting varied between $0.27 \%$ and $19.7 \%$ [23]. In south-eastern Brazil, where rainfall is more abundant, reductions reached $79 \%[22]$.

The use of rainwater harvesting in Lebanon has been successfully implemented for agricultural purposes, with many villages constructing small scale land catchment ponds with a capacity ranging between 1,000 to and $10,000 \mathrm{~m}^{3}$. These ponds have proved to be viable with an attainable return on investment of three to five years [24]. However, the feasibility of promoting urban rainwater harvesting for domestic use remains largely unexplored and has not been incorporated within the National Water Plan.

In this study, the potential of rooftop rainwater harvesting systems in an urban setting is assessed both technically and socio-economically in the context of a fast urbanizing suburb that is facing increasing water shortages. As such, harvested volumes are quantified and compared to existing demands and current deficits, using field ascertained data on building units and water supply systems from the study area. A household survey was developed and administered to assess the willingness of residents to participate and pay as a function of building, demographic, social, water, and educational predictors. The study concludes by arguing the need to adopt rainwater harvesting as a "productive" water source for the future sustainability of water resources in the study area.

\section{METHODOLOGY}

\subsection{Study area}

The Hazmieh/Hadath/Baabda area is a rapidly urbanizing suburb located south-east of Beirut, Lebanon, extending between 50 and 300 meters above sea level. The geographic boundaries of the study area are depicted in Fig. 1. The rainy season spans from November till April with an average annual rainfall of $650 \mathrm{~mm}$. The study area has a population $>23,500$ inhabitants, with most residents living in multi-storey residential buildings. According to the Central Administration of Statistics (CAS), the average number of dwellers per household is five, with a per capita water demand estimated at $180 \mathrm{~L} /$ day [25]. 


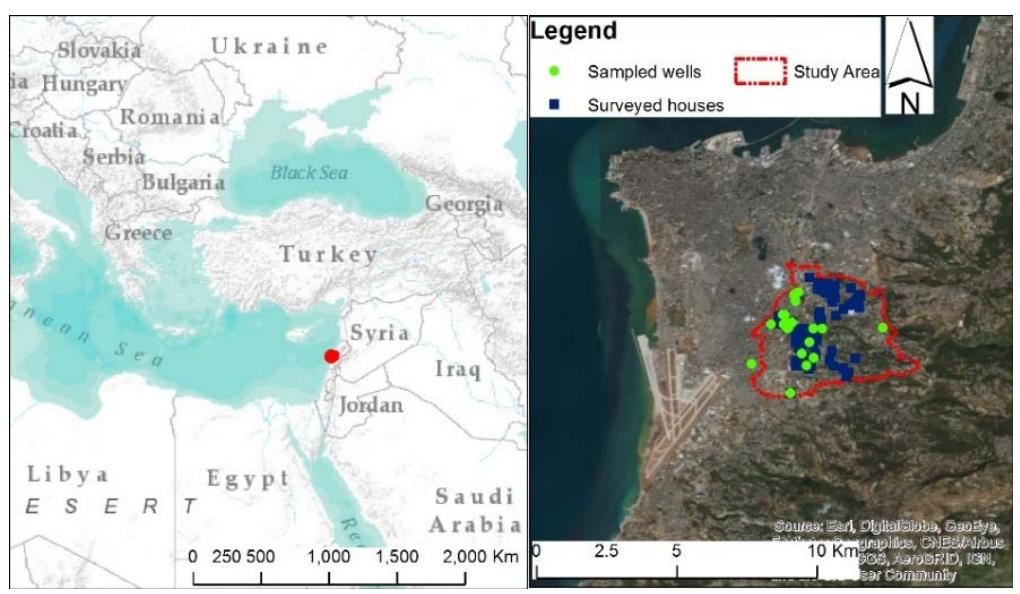

Figure 1: Geographic boundaries of the study area.

\subsection{Household survey}

Primary data were collected using a household survey developed and administered in the study area. A total of 148 household interviews were carried out following a random sampling approach. One-on-one household interviews with household heads living in single houses and multi-storey residential buildings were completed. The questionnaire targeted the collection of data related to socioeconomic and demographic characteristics, water sources, as well as the satisfaction and perception of users regarding network quality. Moreover, the willingness to invest in rainwater harvesting systems was gauged.

\subsection{Water supply}

Like many other urban cities in Lebanon, the public network water supply is the main source of domestic water supplying households. However, water shortages particularly during the summer months are common. Households receive water for a few hours, three days per week during the summer period and up to ten hours every other day during the wet season. Residents pay a fixed annual subscription fee irrespective of the water volume delivered or consumed. When the shortages are accounted for, households end up paying on average $\$ 1.4 / \mathrm{m}^{3}$ of delivered water. Table 1 shows the water supply sources for households in the study area based on responses to the household questionnaire.

Table 1: Water supply sources in the study area. The percentages indicate the number of interviewed households that reported using a given water source.

\begin{tabular}{lccc}
\hline Source of water & Hadath (\%) & Hazmieh (\%) & Baabda (\%) \\
\hline Public network water & 65.0 & 100.0 & 95.7 \\
Well water & 24.0 & 0.0 & 2.2 \\
Water tankers & 48.0 & 63.5 & 52.2 \\
Bottled water & 94.0 & 92.3 & 91.3 \\
Hand-carried water & 6.0 & 1.9 & 2.2 \\
Harvested rainwater & 2.0 & 0.0 & 0.0 \\
\hline
\end{tabular}




\subsection{Water sampling and quality analysis}

Water quality tests were carried out on water samples collected from the tap/network water, private wells, and rainwater at different locations within the study area. A total of twenty tap water samples were collected. Well water samples were also collected from eleven privately owned wells (Fig. 1). The groundwater samples were collected during the rainy season (December) directly from the wellhead. Additionally, rainwater samples were collected on four occasions between March and April from rooftops and gutters of five-storey buildings. Note that unless there is pollution from nearby sources, rainwater is considered a safe water resource. Its quality depends on air quality, receiving roofs, storage tanks, precipitation events, and local weather conditions since prolonged stagnant and dry periods exacerbate the growth of bacteria and other microorganisms; in addition to dust and debris on rooftops. Onelitre plastic bottles were used to collect samples for the physiochemical analysis, while $150 \mathrm{~mL}$ sterilized plastic bottles were used for the bacteriological analysis. Samples were analysed for total and faecal coliforms, total dissolved solids, electrical conductivity, $\mathrm{pH}$, nitrates, sulphates, sodium, potassium, chloride, total hardness, calcium hardness, magnesium hardness, and bicarbonate alkalinity. Analytical tests were performed in accordance to the Standard Methods for the Examination of Water and Wastewater [26] at the Environmental Engineering Research Center at the American University of Beirut.

\subsection{Potential for rainwater harvesting: supply and demand}

A critical step in designing RWHSs is to optimize the rate of supply to meet the water demand. Supply is determined by the amount of rainfall collected on a given rooftop area (eqn (1)) which is dependent on the amount of rainfall, size of the catchment surface, runoff, and water losses due to evaporation.

$$
\mathrm{Q}=\mathrm{P} * \mathrm{~A} * \mathrm{C} / 1000,
$$

where $\mathrm{Q}$ is the potential amount of rainwater that can be harvested from rooftops $\left(\mathrm{m}^{3}\right), \mathrm{P}$ is the amount of rainfall $(\mathrm{mm}), \mathrm{A}$ is the area of the rooftop $\left(\mathrm{m}^{2}\right), \mathrm{C}$ is the runoff coefficient dependent on the type of roof material, and 1000 is the conversion factor from $\mathrm{mm}$ to $\mathrm{m}$.

Daily rainfall data for the study area for a period of 10 years (2001-2010) were obtained from the Rafic Hariri Beirut International Airport meteorological station with Fig. 2 showing the corresponding average monthly distribution of rainfall. Rainfall is seasonal, with a short

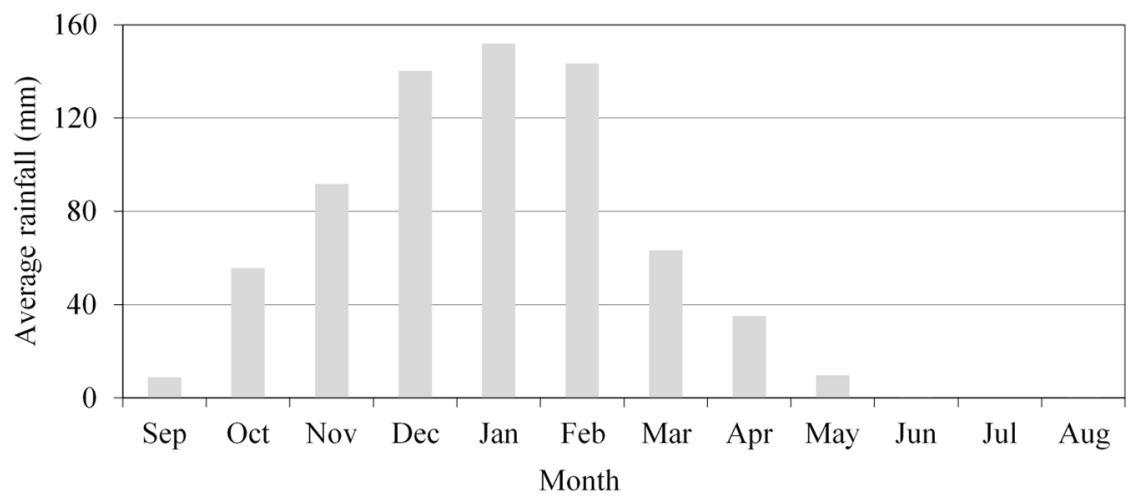

Figure 2: Ten years averaged (2001-2010) monthly rainfall for the study area. 
wet winter and a long dry summer season, typical of a Mediterranean climate. The runoff coefficient $(\mathrm{C})$ is a dimensionless value that estimates the portion of the rainfall that becomes runoff, taking into consideration losses due to spillage, leakage, and evaporation [27]. The runoff coefficient is a function of the roof type, slope, and roughness. According to the household questionnaire, $68 \%$ of households in the study area have cement roofs with a typical runoff coefficient of 0.7 . An average roof area of $300 \mathrm{~m}^{2}$ was adopted, unless indicated otherwise; since the highest percentage of residences were of this size.

Three building types were assessed for a RWHS implementation including a single residence, a five-storey ten apartments building, and a ten-storey twenty apartments building. These types were the most prevalent in the study area. In an effort to estimate potential volumes under different hydrological years, a wet (2003), a dry (2010), and an average (2007) year were selected. Water demands were calculated for an average family size of 5 inhabitants per household, with a per capita consumption of $180 \mathrm{~L} /$ day. The RWHS storage requirements were calculated using the Ripple Method [16] that uses a mass balance, where the capacity of the storage tank is calculated based on monthly demands and precipitation volumes, assuming that $70 \%$ of the rainfall falling on the roof is potentially collected in the storage tank. Consequently, the accumulated rainwater from subsequent months are accounted for in calculating the minimum size of storage tank required for a household given its roof size, average monthly rainfall, and family size [28].

\subsection{Socioeconomic assessment of rainwater harvesting systems}

\subsubsection{Cost of rainwater harvesting systems}

The household scale rainwater harvesting systems were analysed, where water collected on rooftops is channelled through pipes to an underground or elevated storage tank, which many houses already have. In order to analyse the cost of a rainwater harvesting system over its life span, the cost of materials required for installing such a system were obtained from local suppliers and commercial catalogues. The total cost of the system was amortized annually using a 5\% interest rate and a 40-year life span reported for RWHSs in Mediterranean areas [7], [8], [22]. The total cost associated with a RWHS was then compared to the price of network water, the cost of small household reverse osmosis treatment units, and to water purchased from water tankers.

\subsubsection{Willingness to participate}

A logistic regression model was developed to assess the factors affecting the resident's willingness to participate in a RWHS. Several variables were tested for significance including the number of floors, age of the building, purchase of water tankers, satisfaction with current water sources during different seasons, availability of outdoor space to accommodate a rainwater storage tank, the level of trust in public projects, as well as the gender, age and level of education of household respondents. Other socioeconomic variables that were assessed include household ownership and total monthly household income. The logistic linear model is expressed in eqn (2).

$$
\operatorname{logit}(\mathrm{p})=\beta_{0}+\beta_{1} \mathrm{X}_{1}+\beta_{2} \mathrm{X}_{2}+\beta_{3} \mathrm{X}_{3}+\ldots . \beta_{\mathrm{k}} \mathrm{X}_{\mathrm{k}},
$$

where $\mathrm{p}$ is the willingness of a household to participate in a rainwater harvesting program bounded between 0 and 1, the logit is defined as the natural $\log$ of the odds of the outcome or $\ln (\mathrm{p} /[1-\mathrm{p}]), \beta_{0}$ is the baseline constant, $X_{1}$ to $X_{k}$ are $k$ independent variables, and $\beta_{1}$ to $\beta_{\mathrm{k}}$ are model coefficients. All model parameters were estimated based on the maximum likelihood procedure using the glm function in R [29]. 


\subsubsection{Willingness to pay (WTP)}

Willingness to pay is commonly defined as the maximum amount a customer is willing to pay for a given quantity of a product or service [30]. Therefore, it is considered as a critical input for policy makers that aim to implement effective pricing policies. In this context, the main predictors that explained the variability observed in the amount of money people were willing to pay for installing a RWHS based on the household survey were examined. Factors such as age of the building, total number of floors, current sources of water and level of satisfaction, age of household respondent, gender, education level, household ownership, and total monthly household income and expenditure were tested for significance.

\section{RESULTS AND DISCUSSION}

\subsection{Water quality}

Interviewees' perception of the quality of drinking water provided via the public water network was generally negative throughout the study area. Yet, the water quality results were largely within the local standards and WHO guidelines, except for total coliform bacteria, which were present in the vast majority of the samples indicating the presence of organic material in the water source. Only one sample collected from a household connected to the public network had faecal coliform bacteria $(65 \mathrm{CFU} / 100 \mathrm{~mL})$. The microbiological contamination was one of many concerns interviewees raised about the quality of the public network water. When asked about the reasons for their strong negative perception about the water quality, they cited the lack of trust with public authorities, the possibility of contamination due to the absence of wastewater treatment plants in the area, and the objectionable salty taste of the public network water.

Regarding the private wells located, the tested water samples showed high levels of total dissolved solids (TDS) that exceeded the local standards and WHO guidelines. The high TDS levels are due to over-pumping that has promoted the intrusion of seawater into fresh water aquifers. This was evident in the high chloride levels in the samples, whereby 9 out of 11 samples had chloride levels above local standards and WHO guidelines with an average chloride and sodium concentrations of 3,000 and $>200 \mathrm{mg} / \mathrm{L}$, respectively. Moreover, most samples had high levels of microbiological pollution, indicative of sewage contamination.

The $\mathrm{pH}$ of the rainwater collected from the rooftops in Saida, Beirut, and Hazmieh ranged between 5.26 and 6.83. The $\mathrm{pH}$ values of harvested rainwater in Italy and Spain were reported to vary between 5.8 and 8.8 [13], [31], [32]. Chlorides, nitrates, and sulphate concentrations were all within the WHO guidelines. According to Halstead et al. [33], the concentration of sulphates, chlorides, potassium, calcium, and magnesium increases with proximity to coastal areas due to sea salt aerosol containing these ions. The average hardness as $\mathrm{CaCO}_{3}$ was $7.2 \mathrm{mg} / \mathrm{L}$; thus the rainwater is considered to be very soft which offer the benefit of preserving household fixtures (faucets, dishwashers, sink tops, and washing machines), decreasing scum formation, and reducing detergent consumption in case the rainwater is used to meet the laundry demand [8]. Roof rainwater showed the presence of total coliform bacteria in most samples and faecal coliform in $60 \%$ of samples. Microbiological contamination of rooftop runoff can be attributed to the presence of microorganisms in bird droppings such as Salmonella and Campylobacter; in addition to the presence of insects, mammals, and reptiles. Note that samples collected on 24 March 2015 showed the highest levels of microbial contamination across the three areas because the rainfall event on that day occurred following a long dry period; thus rooftops were not clean and bacteria were not washed off prior to 
sampling. In contrast, samples collected on 14 and 23 April, when precipitation had occurred on previous days, exhibited no bacterial contamination.

\subsection{Potential rainwater supply and demand}

The potential amount of rainwater that can be harvested from a rooftop area was calculated, considering the average monthly rainfall during a typical dry, average, and wet year. An estimated $128.5,135.7$, and $182.5 \mathrm{~m}^{3}$ can be potentially harvested annually during the dry, average, and wet years respectively, assuming a $300 \mathrm{~m}^{2}$ roof area. The harvested volumes can cover exclusively the daily water demand of a building with 50 inhabitants for 20 days. For a single household, the volume of harvested rainwater can serve for 203 days. The results showed that during the wettest year (2003), the amount of rainwater that can be harvested exceeded the demand of a single household of 5 inhabitants. During an average year, (2007), the rainwater supply was estimated to cover up to $100 \%$ of the demand for that household. As for the driest year, the amount of rainfall received was estimated to cover up to $60 \%$ of that demand. For multi-storey buildings, the percentage of demand covered by rainwater is minimal irrespective of the hydrological year. While the volume harvested may be minimal with respect to the total demand, its contribution towards reducing the deficit between demand and supply is promising. Fig. 3 shows that the water deficit can be reduced between 5\% and $93 \%$ for buildings with 5 and 20 apartments with a maximum rooftop area of $220 \mathrm{~m}^{2}$.

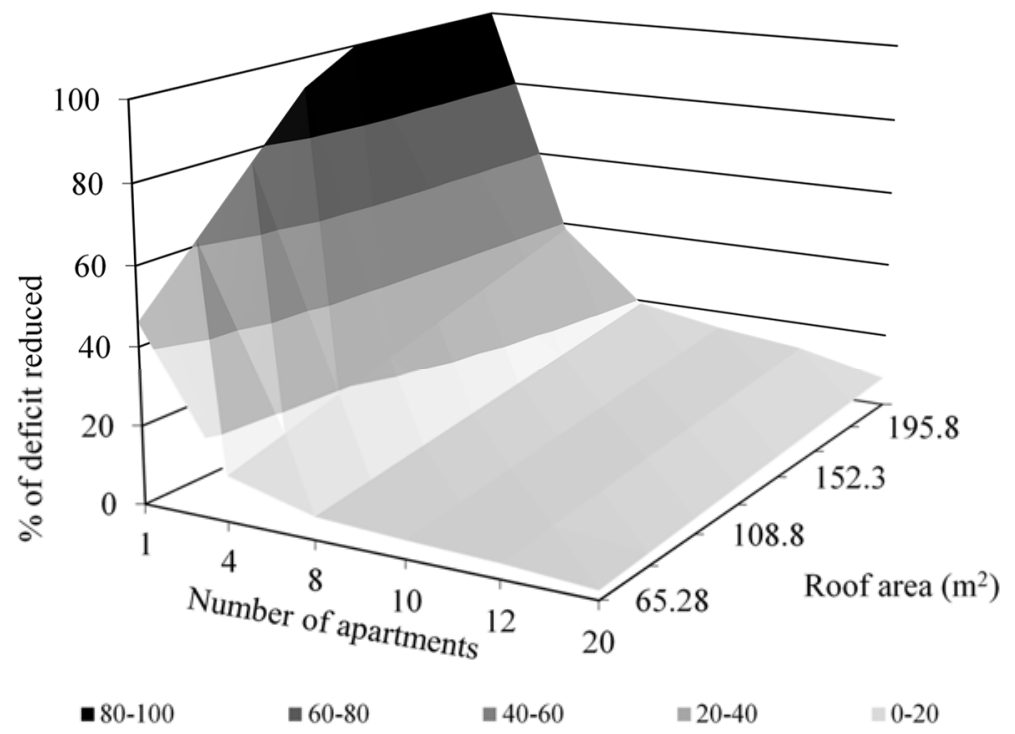

Figure 3: Percentage of deficit reduced as a function of rooftop area and number of apartments.

The sizing of the storage tank depends on local conditions such as average rainfall, water demand, catchment area, space area availability, and budget. The needed storage tank sizes for buildings with four apartments or more are reasonable since the estimated amount of collected rainwater will often not carry over from month to month due to the high daily 
demand and the limited supply. Whereas for a single apartment-household, a surplus in excess of $22 \mathrm{~m}^{3}$ is expected in the month of February, requiring a $25 \mathrm{~m}^{3}$ storage tank to prevent the overflow of rainwater. Note that due to the intermittent supply of water, many households already have one or several water storage tanks that can be used to collect harvested rainwater in a building after treatment. This option can overcome limitations such as the availability of space for installing storage tanks or the difficulty of re-plumbing an entire building to create dedicated water supply lines to link harvested rainwater directly to toilets or washing machines. Most new buildings in the area have an underground storage tank with a capacity ranging from 20 to $40 \mathrm{~m}^{3}$ intended to store water received from the network or purchased water.

\subsection{Socioeconomic assessment}

\subsubsection{Economic analysis}

The RWHS can help in reducing water shortages in the study area. Yet, the associated costs with these systems will primarily drive their market penetration. The capital investment for a RWHS was estimated to vary between $\$ 2,100$ and $\$ 9,500$ depending on the capacity of the installed storage tank (between 5 and $40 \mathrm{~m}^{3}$ ). The price of the storage tank represents the largest portion for installing a RWHS, reaching 30-45\% of the total cost of the system depending on the tank's material and size. The installation of a RWHS during building construction will generally cost less than retrofitting a system in an existing building because of the extra costs associated with the plumbing changes needed as well as the installation of downpipes to deliver rainwater from the roof into the storage tanks located at the ground level. Accounting for operation and maintenance costs as well as energy costs to pump water from the storage tank to the household, the total cost of rainwater (amortized capital cost plus recurrent costs) harvested in a $5 \mathrm{~m}^{3}$ storage tank is estimated at $\$ 125$ per year, considering a $5 \%$ interest rate and a 40 year life span of the system. Thus, the cost of harvested rainwater per cubic meter is $\$ 0.28$ assuming a $300 \mathrm{~m}^{2}$ rooftop area. The cost drops to $\$ 0.16 / \mathrm{m}^{3}$ when the storage tank's capacity is increased to $40 \mathrm{~m}^{3}$, which is comparable to the current tariff on network water. Moreover, rainwater harvesting competes favourably with the adaptation measures that people are resorting to in an effort to overcome chronic water shortages whereby residents are reported to pay $\$ 1.36 / \mathrm{m}^{3}$ for water from a reverse osmosis system and up to $\$ 10 / \mathrm{m}^{3}$ for water delivered by tankers according to the household survey.

\subsubsection{Household survey}

Nearly $77 \%$ of household interviewees expressed support to a RWHS. Many viewed rainwater as a complementary water supply source that can contribute to alleviating scarcity and reduce over-exploitation of aquifers. When it comes to their preferred uses for the harvested rainwater, $64.4 \%$ of respondents stated their willingness to use rainwater for all household usages except drinking; $31.1 \%$ believed that rainwater was suitable for potable purposes if properly managed. The remaining $4.5 \%$ believed that rainwater was only good for outdoor usages such as car washing and landscaping.

\subsubsection{Willingness to participate}

Several factors proved to be significant in explaining respondents' willingness to participate in a rainwater harvesting program (Table 2). The four most significant determinants of interviewees' willingness to participate were age, presence of outdoor space area, highest level of education, and number of floors in the building. 
Table 2: Willingness to participate based on logistic regression.

\begin{tabular}{lcccc}
\hline Predictor & Estimate & Standard error & Z-value & Significance \\
\hline Intercept & 7.187 & 2.782 & 2.584 & 0.010 \\
(Age: 50)/10 & -0.662 & 0.327 & -2.028 & 0.043 \\
Absence of outdoor space & -7.084 & 2.157 & -3.285 & 0.001 \\
Holder of university degree & 1.732 & 1.002 & 1.729 & 0.084 \\
Building floor: 2 & -0.671 & 0.347 & -1.931 & 0.053 \\
\hline
\end{tabular}

To provide a meaningful intercept to the model, age was reported in decades after centering on 50 years. Similarly, the number of floors in buildings was centered on a two storey building. As such, a respondent aged 50, with no university degree, and living in a two storey building with access to an outdoor space is almost certainly willing to participate with a probability $>99.99 \%$. When lacking access to an outdoor space, the probability of participation dropped to $52.6 \%$. In the event that the respondent had a university degree, the probability of participation increased by five folds. For every additional floor, the odds of participation dropped by half. Older respondents were less likely to adopt rainwater harvesting. With every ten years of age, the odds of adopting a RWHS dropped by $51.6 \%$. The multivariate model accounted for 0.2 (McFadden's pseudo $\mathrm{R}^{2}$ ) and 0.3 (Cragg and Uhler's pseudo $\mathrm{R}^{2}$ ) of the proportion of the total variability of the outcome depending on the pseudo $\mathrm{R}^{2}$ equation used [34].

\subsubsection{Willingness to pay}

Given that the only significant predictor was the monthly household income, an ANOVA test was used to predict the variability within a particular income group while testing for interincome group variability. In other words, people's willingness to pay (WTP) for a RWHS was only found to significantly vary as a function of the income of the household (p-value $<$ 0.05 ). Note that a log transformation was applied on all monthly income groups in an effort to normalize the data. Monthly incomes were divided into 4 groups: $<\$ 1,500, \$ 1,500$ $\$ 4,000, \$ 4,000-\$ 6,000$, and $>\$ 6,000$. The ANOVA analysis showed that household income was a significant predictor of the WTP for all 4 groups. On average, a household with a monthly income $<\$ 1,500$ was willing to pay $0.54 \$ / \mathrm{m}^{3}$ to install a RWHS in case the current source of water is no longer available as compared to $\$ 2.34 / \mathrm{m}^{3}$ for those with an income $>\$ 6,000 /$ month. A comparison between the price a family of 5 is currently paying for $1 \mathrm{~m}^{3}$ of water delivered by water tankers $\left(\$ 5.64 / \mathrm{m}^{3}\right)$, and network water $\left(\$ 0.37 / \mathrm{m}^{3}-\$ 1.4 / \mathrm{m}^{3}\right)$ to account for water shortage, reveals that residents' WTP closely relate to the high costs they incur by purchasing water from other sources.

\section{CONCLUSION AND RECOMMENDATIONS}

Water shortage is a critical challenge facing many urban areas. This study demonstrated that while rainwater harvesting cannot be the sole solution that will alleviate water scarcity in the study area, it can easily complement existing public and private water systems. It can provide an appreciable water resource for developing a sustainable supply for the study area in light of increased demand and limited conventional water sources. New buildings can adopt this system and make use of the harvested water for non-potable uses with successful examples reported in similar semi-dry urban context [8], [35]. While roof-collected rainwater, in general, meets the classical physico-chemical parameters for drinking water, microbiological properties of tested samples (coliforms) exceeded acceptable limits. As such, periodic water quality monitoring is needed to both recommend the type of treatment systems required as 
well as to ensure safe usage of rainwater, especially when stored in a common tank with network water. The installation of first flow diverters can avoid using low quality water due to the accumulation of dirt or debris.

While the ability to capture rainwater on a larger scale was not examined in this study, some limitations are expected such as the availability of space to construct a catchment area to store rainwater harvested from rooftops, pavements, roads, and parking. Water quality and willingness to participate in such a plan may present additional constraints. The household survey showed that residents have a lack of trust in large projects adopted at the central level and tend to favour projects where they can operate and maintain the system themselves.

\section{ACKNOWLEDGEMENTS}

This study was funded through a program on climate change and sea water intrusion along the Eastern Mediterranean funded by the International Development Research Center (IDRC) of Canada at the American University of Beirut Grant No. 106706-001. Funding was also provided by the Deutsche Gesellschaft für Internationale Zusammenarbeit (GIZ) through a program on managed aquifer recharge to prevent seawater intrusion in Beirut - Lebanon.

\section{REFERENCES}

[1] Sánchez, A.S., Nogueira, I.B.R. \& Kalid, R.A., Uses of the reject brine from inland desalination for fish farming, spirulina cultivation, and irrigation of forage shrub and crops. Desalination, 364, pp. 96-107, 2015.

[2] Aladenola, O.O. \& Adeboye, O.B., Assessing the potential for rainwater harvesting. Journal of Water Resources Management, 24(10), pp. 2129-2137, 2010.

[3] Herrmann, T. \& Schmida, U., Rainwater utilization in Germany: Efficiency, dimensioning, hydraulic and environmental aspects. Urban Water, 1(4), pp. 307-316, 2000.

[4] Nolde, E., Possibilities of rainwater utilization in densely populated areas including precipitation runoffs from traffic surfaces. Desalination, 215(1-3), pp. 1-11, 2007.

[5] Zhang, Y., Chen, D., Chen, L. \& Ashbolt, S., Potential for rainwater use in high-rise buildings in Australian cities. Journal of Environmental Management, 91(1), pp. 222226, 2009.

[6] Morales-Pinzón, T., Lurueña, R., Rieradevall, J., Gasol, C.M. \& Gabarrell, X., Financial feasibility and environmental analysis of potential rainwater harvesting systems: A case study in Spain. Resources, Conservation and Recycling, 69, pp. 130140, 2012.

[7] Farreny, R., Gabarrell, X. \& Rieradevall, J., Cost-efficiency of rainwater harvesting strategies in dense Mediterranean neighbourhoods. Resources, Conservation and Recycling, 55(7), pp. 686-694, 2011.

[8] Farreny, R., Morales-Pinzón, T., Guisasola, A., Tayà, C., Rieradevall, J. \& Gabarrell, X., Roof selection for rainwater harvesting: Quantity and quality assessments in Spain. Water Research, 45(10), pp. 3245-3254, 2011.

[9] Domènech, L., Heijnen, H. \& Saurí, D., Rainwater harvesting for human consumption and livelihood improvement in rural Nepal: Benefits and risks. Water and Environment Journal, 26(4), pp. 465-472, 2012.

[10] Said, S., Assessment of roof-top rain water harvesting potential in south Delhi, India: A case study. International Journal of Environmental Research and Development, 4(2), pp. 141-146, 2014. 
[11] Jones, M.P. \& Hunt, W.F., Performance of rainwater harvesting systems in the southeastern United States. Resources, Conservation and Recycling, 54(10), pp. 623-629, 2010.

[12] Lye, D.J., Rooftop runoff as a source of contamination: A review. Science of the Total Environment, 407(21), pp. 5429-5434, 2009.

[13] Sazakli, E., Alexopoulos, A. \& Leotsinidis, M., Rainwater harvesting, quality assessment and utilization in Kefalonia island, Greece. Water Research, 41(9), pp. 2039-2047, 2007.

[14] Aklan, M.M., The potential of rooftop rainwater harvesting for Sana'a, Yemen. MSc thesis, University of Jordan and the Institute of Technology and Resources Management in the Tropics and Subtropics (ITT), University of Applied SciencesCologne, 2011.

[15] Angrill, S., Farreny, R., Gasol, C.M., Gabarrel, X., Vinolas, B. \& Josa, A., Environmental analysis of rainwater harvesting infrastructures in diffuse and compact urban models of Mediterranean climate. The International Journal of Life Cycle Assessment, 17(1), pp. 25-42, 2012.

[16] Texas Water Development Board, The Texas Manual on Rainwater Harvesting, 3rd edn, eds C. Brown, J. Gerston, S. Colley \& H.J. Krishna, Austin, TX, 2005.

[17] Cardona, C., An integrated approach towards assessing the feasibility of domestic rainwater harvesting in Malta. MSc thesis, School of Geography and the Environment, University of Oxford, UK, 2006.

[18] Campisano, A., Gnecco, I., Modica, C. \& Palla, A., Designing domestic rainwater harvesting systems under different climatic regimes in Italy. Water Science \& Technology, 67(11), pp. 2511-2518, 2013.

[19] Lange, J., Husary, S., Gunkel, A., Bastian, D. \& Grodek, T., Potentials and limits of urban rainwater harvesting in the Middle East. Hydrology and Earth System Sciences, 16, pp. 715-724, 2012.

[20] Bates, B., Kundzewicz, Z.W., Wu, S. \& Palutikof, J., Climate change and water: Technical paper of the intergovernmental panel on climate change. Technical Report, IPCC: Geneva, 2008.

[21] Palla, A., Gnecco, I., Lanza, L.G. \& La Barbera, P., Performance analysis of domestic rainwater harvesting systems under various European climate zones. Resources, Conservation and Recycling, 62, pp. 71-80, 2012.

[22] Domènech, L. \& Saurí, D., A comparative appraisal of the use of rainwater harvesting in single and multi-family buildings of the metropolitan area of Barcelona (Spain): Social experience, drinking water savings and economic costs. Journal of Cleaner Production, 19(6-7), pp. 598-608. 2011.

[23] Abdulla, F.A. \& Al-Shareef, A.W., Roof rainwater harvesting systems for household water supply in Jordan. Desalination, 243(1-3), pp. 195-207, 2009.

[24] Hayek, C., Maintaining rainwater harvesting practices in southern Lebanon: The kaza of tyre. MSc thesis, Massachusetts Institute of Technology, Cambridge, USA, 2009.

[25] Ministry of Environment (MoE), Lebanon state of the environment report. Ministry of the Environment/LEDO/ECODIT: Beirut, Lebanon. 2001.

[26] American Public Health Association (APHA), Water Environment Federation (WEF), \& American Water Works Association (AWWA), Standard Methods for the Examination of Water and Wastewater, 21st edn, American Public Health Association: Washington, DC, 2005.

[27] Singh, V.P., Elementary Hydrology, Prentice Hall: Englewood Cliffs, NJ, pp. 263, 1992. 
[28] Tomaz, P., Utilization of water for non-drinkable purposes in urban areas. International Journal of Sustainable Build Environment, 2(2), pp. 109-118, 2003.

[29] R Core Team, R: A Language and Environment for Statistical Computing, R Foundation for Statistical Computing: Vienna, Austria, 2014.

[30] Wartenbronch, K. \& Skiera, B., Measuring consumer's willingness to pay at the point of purchase. Journal of Marketing Research, 39(2), pp. 228-241, 2002.

[31] Schriewer, A., Horn, H. \& Helmreich, B., Time focused measurements of roof runoff quality. Corrosion Science, 50(2), pp. 384-391, 2008.

[32] Villarreal, E.L. \& Dixon, A., Analysis of a rainwater collection system for domestic water supply in Ringdansen, Norrköping, Sweden. Building and Environment, 40(9), pp. 1174-1184, 2005.

[33] Halstead, M.J.R., Cunninghame, R.G. \& Hunter, K.A., Wet deposition of trace metals to a remote site in Fiordland, New Zealand. Atmospheric Environment, 34(4), pp. 665$676,2000$.

[34] Long, S.J., Regression Models for Categorical and Limited Dependent Variables, Advanced Quantitative Techniques in the Social Sciences, SAGE Publications: Thousand Oaks, CA, 1997.

[35] Liaw, C.H. \& Tsai, Y.L., Optimum storage volume of rooftop rainwater harvesting systems for domestic use. Journal of American Water Resources Association, 40(4), pp. 901-912, 2007. 